\title{
CRITICAL EVALUATION OF IN VITRO METHODS FOR ESTIMATING DIGESTIBILITY IN SIMPLE-STOMACH ANIMALS
}

\section{S. BOISEN AND B. O. EGGUM}

National Institute of Animal Science, Foulum, DK-8830 Tjele, Denmark

\section{CONTENTS}

INTRODUCTION .

IN VIVO DIGESTION IN SIMPLE-STOMACH ANIMALS . . . . 142

STOMACH. . . . . . . . . . . . . . . . 143

SMALL INTESTINE . . . . . . . . . . . . . . . . . . . . 143

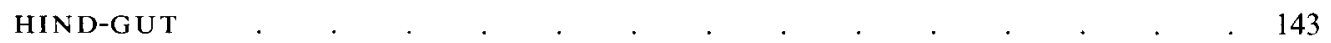

FACTORS INFLUENCING DIGESTIBILITY IN VIVO • . . . . . . . . 144

IN VITRO METHODS FOR ESTIMATING DIGESTIBILITY. . . . 145

DIALYSIS CELL METHOD . . . . . . . . . . . . . . 145

Objective . . . . . . . . . . . . . . . . . . . 145

Principle . . . . . . . . . . . . . . . . . 145

Methods. . . . . . . . . . . . . . . 145

Results . . . . . . . . . . . . . . . 145

Discussion . . . . . . . . . . . . . . 146

PH-DROP AND PH-STAT METHOD . . . . . . . . . . . 146

Objective . . . . . . . . . . . . . . . . . . . . . 146

Principle . . . . . . . . . . . . . . . . . . 146

Methods. . . . . . . . . . . . . . . 146

Results . . . . . . . . . . . . . . . . 146

Discussion . . . . . . . . . . . . . . . . . . . 147

COLORIMETRIC METHODS

Objective . . . . . . . . . . . . . . . . . . . . . . . . . 147

Principle . . . . . . . . . . . . . . . . 147

Methods. . . . . . . . . . . . . . . . . 147

Results . . . . . . . . . . . . . . . 148

Discussion . . . . . . . . . . . . . . . . . . 148

'FILTRATION' METHODS . . . . . . . . . . . . . 148

Objective . . . . . . . . . . . . . . . . . . . . 148

Principle . . . . . . . . . . . . . . . 148

Methods. . . . . . . . . . . . . . . . . . 148

Intestinal fluids . . . . . . . . . . . . . . . . . . . . 149

Pepsin-jejunal fluid . . . . . . . . . . . . . . . . . . . . . 149 
Pepsin-pancreatin . . . . . . . . . . . . . . . 149

Pepsin-pancreatin-rumen fluid . . . . . . . . . . . . . . . . 149

Pepsin-pancreatin-fibre-degrading enzymes . . . . . . . . . 150

Results . . . . . . . . . . . . . . 150

Discussion . . . . . . . . . . . . . . . . . . . . . . . 152

GENERAL DISCUSSION . . . . . . . . . . . . . . . . 153

FACTORS INFLUENCING DIGESTIBILITY IN VITRO . . . . . . . . 153

Enzyme specifity . . . . . . . . . . . . . . . . . . 153

Enzyme activity . . . . . . . . . . . . . . . . . . . . 154

Sample and particle size . . . . . . . . . . . . . . . . . . . . . 155

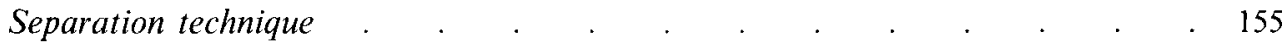

RELATIONSHIP BETWEEN IN VITRO AND IN VIVO RESULTS . . . . 155

Prediction of in vivo digestibility . . . . . . . . . . . . . . . . . . $\quad$. 155

Prediction of in vivo availability . . . . . . . . . . . . . . . . . . 157

Prediction of feed value. . . . . . . . . . . . . . . . . . . 158

CONCLUSIONS . . . . . . . . . . . . . . . . . . . . . 158

REFERENCES . . . . . . . . . . . . . . . . . . . . . . 159

\section{INTRODUCTION}

When predicting the nutritional quality of foods, information on the digestibility of the various nutrients is of utmost importance. However, in vivo determinations are timeconsuming and costly, which is why much effort has been devoted to the development of in vitro procedures. To simulate the in vivo situation in vitro, one has to consider not only host enzyme digestion but also the microbial activity in the digestive tract, which often can have a great impact on overall digestibility. Due to the hind-gut fermentation in simplestomach animals, many workers in digestive physiology (e.g. Tanksley \& Knabe, 1984; Just et al. 1985; Sauer \& Ozimek, 1986) have recommended that digestibility, particularly of amino acids, be measured at the terminal ileum. The present review will not deal with this discussion, but rather will present comparative ileal and faecal digestibility values, and relate these to in vitro values. The various approaches described in the literature will be discussed and evaluated. Particular emphasis will be given to feeds for simple-stomach animals such as pigs and poultry. However, some aspects of human nutrition will also be discussed briefly.

When reviewing the various techniques, special attention will be given to simple, rapid and reproducible in vitro procedures. Furthermore, the validation of the in vitro methods will be based on the degree of relationship between in vitro and in vivo results from identical materials.

\section{IN VIVO DIGESTION IN SIMPLE-STOMACH ANIMALS}

When developing in vitro digestibility techniques it is logical to simulate one or more steps of the in vivo conditions. Therefore, some aspects of the digestive physiology in the stomach, small intestine and hind-gut of simple-stomach animals will be briefly outlined. 


\section{STOMACH}

In the stomach, the hydrolysis of proteins is initiated by the action of pepsin (EC 3.4.23.1) and hydrochloric acid. At least half the proteins leaving the stomach are usually in the form of peptides, with a large proportion being soluble in trichloroacetic acid (TCA), i.e. peptides having ten or fewer amino acids (Low, 1990).

The hydrolysis of starch and fat is also initiated in the stomach by salivary amylase $(E C$ $3.2 .1 .1)$ and gastric lipase $(E C 3.1 .1 .3)$ respectively. Gastric lipolysis seems quantitatively important for the release of short- and medium-chain fatty acids from triacylglycerols, the main reaction products being diacylglycerols and fatty acids. Thus, gastric lipolysis may be important in the digestion of some dietary fats, but only hydrolysis is effected. Emulsification does not occur in the stomach (Friedman \& Nylund, 1980).

\section{SMALL INTESTINE}

Proteins and peptides passing from the stomach are further hydrolysed in the small intestine by the pancreatic proteinases trypsin $(E C 3.4 .21 .4)$, chymotrypsin $(E C 3.4 .21 .1)$ and elastase $(E C$ 3.2.21.36) and the peptidases, carboxypeptidases $A(E C$ 3.4.17.1) and B (EC 3.4.17.2). Dissolved brush-border peptidases may finally contribute to the hydrolysis before absorption of free amino acids and di- and tripeptides. Although the ileum has considerable digestive and absorptive capacity, the absorption of dietary protein occurs mainly in the proximal jejunum (Grimble \& Silk, 1989).

The hydrolysis of starch polymers, already started by salivary amylase in the mouth and stomach, is continued by pancreatic amylase in the lumen of the small intestine. The endproducts maltose, maltotriose and $\alpha$-limit dextrins are finally hydrolysed to glucose by maltase (EC 3.2.1.20), sucrase (EC 3.2.1.48), and isomaltase (EC 3.2.1.10) (Roehrig, 1984). Dietary disaccharides like lactose and sucrose are hydrolysed to monosaccharides by lactase (EC 3.2.1.108) and sucrase. All hydrolase enzymes involved in the hydrolysis to monosaccharides are bound to the apical membrane of the enterocytes with their active sites projecting into the intestinal lumen.

The hydrolysis of fats in the small intestine is catalysed by at least three different enzymes and one coenzyme (colipase) from pancreatic juice. These enzymes are (1) pancreatic lipase, which is rather non-specific and splits triacylglycerols into monoacylglycerols and fatty acids, (2) carboxylic ester hydrolase (EC 3.1.1.1), which splits carboxylic esters, and (3) phospholipase $\mathrm{A}_{2}$ ( $E C$ 3.1.1.4), which hydrolyses fatty acids in the 2-position of glycerophospholipid. The activity of lipase is enhanced by the presence of bile salts, while the two latter enzymes have an absolute requirement for bile salts. Bile salts also promote absorption of long-chain fatty acids and monoacylglycerols, due to their solubilizing effect, which increases the transport across the unstirred water layer between gut lumen and brush border (Friedman \& Nylund, 1980). Fat absorption occurs mainly in the jejunum. As digestion progresses, the lipid phase decreases in volume and the products of digestion pass into mixed micelles which are large molecular aggregates consisting of monoacylglycerols, long-chain fatty acids, bile salts and phosphoacylglycerols. The mixed micelles are able to draw into the hydrophobic core the less-water-soluble molecules such as cholesterol, carotenoids, tocopherols, and some undigested triacylglycerols (Gurr et al. 1989).

\section{HIND-GUT}

The major site of assimilation of endogenously derived protein (intestinal secretions, secreted plasma proteins and desquamated cells) is assumed to be the hind-gut. The $\mathrm{N}$ endogenous losses from the small intestine are about $10-20 \%$ of $N$ intake (Grimble \& Silk, 
1989). However, the microflora in the large intestine are capable of digesting endogenous proteins (e.g. mucin) as well as exogenous proteins. Luminal hydrolysis of protein continues by the action of undegraded pancreatic enzymes as well as secreted and cell-wallbound bacterial peptidases. The released amino acids may be incorporated into microbial protein or deaminated and fermented to short-chain fatty acids.

The carbohydrate residues in the hind-gut consist of undigested starches, oligosaccharides and non-starch polysaccharides (NSP). In this region there are no endogenous enzymes capable of degrading these residues. However, the gut microflora are able to hydrolyse most of the bonds in those compounds which are partly available such as pectins and $\beta$-glucans. The released monosaccharides are fermented by the microflora. The endproducts are primarily short-chain fatty acids which can be absorbed and act as an energy source for the host animal.

Fatty acids cannot be fermented, which is why the amount of lipid is only marginally influenced during passage through the hind-gut. On the other hand, unsaturated fatty acids may be hydrogenated, while lipids can be synthesized in this part of the digestive tract. Both factors complicate the measurements of digestibility of individual fatty acids (e.g. Eggum et al. 1982).

\section{FACTORS INFLUENCING DIGESTIBILITY IN VIVO}

The digestive capacity can be modified by numerous stimuli, e.g. the food itself. Thus, the enzymes which are involved with protein, carbohydrate and lipid digestion adapt to any changes in substrate intake (Corring 1980; Corring et al. 1989; Eggum et al. 1989; Savoie et al. 1989). This means primarily that an increase in dietary protein induces an increased secretion of pancreatic proteolytic enzymes, while an increase in starch or lipid intake induces increased secretions of amylase and lipase respectively. Also, antinutritional factors (ANF) and dietary fibre affect enzyme secretions.

Several specific responses of ANF on digestibility are known. Thus, trypsin inhibitors increase the pancreatic secretion of trypsin and other enzymes (Liener \& Kakade, 1980), while tannins may induce a large increase in specific proline-rich proteins in the saliva. These proteins have a very high affinity for tannins and are therefore assumed to play a role in reducing the adverse effect of tannins on protein digestibility (Mehansho et al. 1987). Lectins, however, interfere with the digestion and absorption processes in quite a different way as they bind to surface receptors of the enterocytes and thus induce changes in epithelial cell metabolism, thereby increasing cellular turnover and protein secretion (Pusztai, 1989). The main effect of ANF on digestibility is probably an increased loss of endogenous protein rather than a negative effect on digestibility of exogenous protein. Normally, there is a great surplus of digestive capacity in the small intestine (Low, 1980).

Dietary fibre will influence in vivo digestion in several ways, depending on the nature of the fibre. Dietary fibre can thus reduce enzyme activity in the lumen, but probably also protects the enzymes against degradation (Boisen et al. 1985). Furthermore, anatomical changes of certain parts of the digestive tract by fibre can be seen (Eggum, 1991). Fibre will in general stimulate microbial activity in the digestive tract significantly and reduce transit time of the digesta.

Although most of the bacterial metabolism takes place in the hind-gut, digestion can be influenced by the microflora throughout the whole gastrointestinal tract. Thus, monosaccharides may be fermented in the upper part of the gastrointestinal tract to volatile fatty acids and various gases. The energy in the absorbed volatile fatty acids will be of value to the host animal, but the net utilization will be much lower than that if the monosaccharide had been absorbed without modification. Furthermore, the bacterial flora can synthesize as 
well as degrade the individual amino acids (Mason, 1984). Thus, due to the microbial activity in the upper tract, the ileal apparent digestibility values are not necessarily exact measures of net absorbed amino acids.

Finally, it should also be mentioned that food utilization is influenced by several other factors such as management, environment, disease and genetic capability. In this regard, Elbers et al. (1989) found organic-matter digestibility of the same diet on seventeen pig farms to vary from 75 to $85 \%$ for a grower diet, and from 78 to $86 \%$ for a finisher diet.

\section{IN VITRO METHODS FOR ESTIMATING DIGESTIBILITY}

From the previous discussion it is apparent that many factors are involved in in vivo digestibility. Therefore, the in vivo conditions can never be completely simulated under in vitro conditions. The in vitro technique can be designed to use specific enzymes either to give maximal digestibility values or to measure the initial rate of hydrolysis. In both cases the enzymes used should have specificities similar to those which are present in the digestive tract. The applicability of the results depends on a high correlation with in vivo values obtained under standardized conditions using identical material. In the following discussion, the different methods are described according to their objectives, principles, use of specific enzymes, and demands for special equipment. Evaluation of the methods is based on the reported results.

\section{DIALYSIS CELL METHOD}

\section{Objective}

To study the influence of various factors on the digestion of protein (and other nutrients) when end-product inhibition is prevented.

\section{Principle}

Enzymic digestion of proteins with continuous removal of low-molecular-weight products by dialysis.

\section{Methods}

Samples containing $40 \mathrm{mg} \mathrm{N}$ are suspended in diluted hydrochloric acid at $\mathrm{pH} 1.9$ and digested with pepsin for $30 \mathrm{~min}$. After adjusting the $\mathrm{pH}$ to 7.5 with sodium hydroxide, the mixture is poured into the dialysis tube (molecular weight cut-off 1000) of the digestion cell with a pancreatin solution and digested with continuous stirring for $6 \mathrm{~h}$. Digestion products are collected from the external compartment by sodium phosphate buffer circulation. The collected products are analysed for nitrogen and for amino acids (Gauthier et al. 1986; Savoie \& Gauthier, 1986). This method has been developed from previously described methods (Mauron et al. 1955; Steinhardt \& Kirchgessner, 1973; Gauthier et al. 1982).

\section{Results}

Gauthier et al. (1982) observed that the degree of digestion of casein, soya-bean and rapeseed protein was markedly increased by buffer replacements, indicating inhibition by end-products as suggested by Robbins (1978). By this procedure the deleterious effect of heat and alkali treatment on protein digestion was clearly demonstrated (Vachon et al. 1983).

The method can also be used for direct measurement of peptide susceptibility to hydrolysis by proteolytic enzymes. Thus, Brulé \& Savoie (1988) found that basic and 
aromatic amino acids were generally the most readily liberated, while cystine and proline were the least digested in six common protein sources comprising casein, field peas ( $P$ isum sativum), peanut meal, rapeseed, soya bean and wheat flour. However, the kinetics of hydrolysis of peptide bonds and release of amino acids and peptides depends on the different specificities of the enzymes involved. Savoie \& Charbonneau (1990) demonstrated by adding trypsin and chymotrypsin to pancreatin that the optimal combination of enzymes differed from one substrate to another.

The influence of the time factor was investigated by Galibois et al. (1989) by comparing the essential amino acid (EAA) profiles in the dialysate collected at $3 \mathrm{~h}$ intervals during $24 \mathrm{~h}$ of in vitro enzymic proteolysis of casein and rapeseed protein with the pattern of appearance of dietary EAA in the portal vein of pigs fed on the same proteins. The results demonstrated a close relationship between the in vitro release of amino acids and the appearance of dietary EAA in the portal vein.

\section{Discussion}

The dialysis cell method appears to be very valuable for studying luminal protein degradation in the small intestine and also seems able to predict the availability of amino acids. Furthermore, this technique can be used for studying starch degradation, as recently reported by Drake (1991), and may be used to measure enzymic release of any soluble lowmolecular-weight product from a high-molecular-weight substrate.

\section{pH-DROP AND pH-STAT METHOD}

\section{Objective}

To predict protein digestibility in foods.

\section{Principle}

During proteolysis, protons are released from the cleaved peptide bonds, resulting in a decrease in $\mathrm{pH}$ in a suspension. Assuming a correlation between the initial rate of peptide release and protein digestibility, the latter can be predicted by (1) recording the decrease in $\mathrm{pH}$ (pH-drop method) or (2) keeping the $\mathrm{pH}$ constant with continuous addition of $\mathrm{NaOH}$ and measuring $\mathrm{NaOH}$ consumption ( $\mathrm{pH}$-stat method),

\section{Methods}

Samples containing $10 \mathrm{mg} \mathrm{N}$ are suspended in $10 \mathrm{ml}$ distilled water, adjusted to $\mathrm{pH} 8.00$ and equilibrated at $37^{\circ}$. A solution of trypsin, chymotrypsin and peptidase $(1 \mathrm{ml})$ is added to the protein suspension, and after exactly $10 \mathrm{~min}$ of incubation, $\mathrm{pH}$ is recorded (Hsu et al. 1977). A modified method incubating additionally with a proteinase from Streptomyces griseus has been described by Satterlee et al. (1981). In the $\mathrm{pH}$-stat method, $\mathrm{pH}$ is kept constant by automatic titration with $0 \cdot 1 \mathrm{M}-\mathrm{NaOH}$. At the end of the incubation period the amount of alkali added is recorded (Pedersen \& Eggum, 1983).

\section{Results}

The in vitro digestibility obtained with the $\mathrm{pH}$-drop method has been found to be highly correlated with apparent faecal digestibility of protein in rats in investigations on a variety of plant proteins (Hsu et al. 1977; Satterlee et al. 1981). However, both the pH-drop and $\mathrm{pH}$-stat methods have given poor agreement with in vivo values for a great variety of foods and feedstuffs (Pedersen \& Eggum, 1981; Wolzak et al. 1981). These authors found it necessary to use different regression equations for each class of food to obtain a reliable estimate of digestibility. Some of the problems were obviously related to different buffer 
capacities in the incubated materials. This was demonstrated by Moughan et al. (1989) investigating twenty meat-and-bone samples. The authors compared the results obtained with the four-enzyme method with in vivo true ileal protein digestibility obtained with rats. A significant relationship was found between the pH-drop and in vivo digestibility. However, meat-and-bone meal samples which were highly digestible in vivo caused a low initial drop in $\mathrm{pH}$, which is opposite to what was expected. The explanation for this was a negative correlation between $\mathrm{pH}$-drop and ash content in the samples, suggesting a strong buffering capacity of meat-and-bone meal due to the high mineral content (mean ash $275 \mathrm{~g} / \mathrm{kg}$ ).

The in vitro digestibility obtained with the $\mathrm{pH}$-stat method has been correlated with true protein digestibility values determined in rats. Compared with the $\mathrm{pH}$-drop method, the $\mathrm{pH}$-stat method improved the prediction of protein digestibility, and the same regression equation could be used for a variety of materials. In general a good agreement has been obtained with faecal true digestibility of plant protein $(n 31, r 0.85$, residual standard deviation (RSD) 2.4) as well as with the proteins of animal origin ( $11, r 0.92$, RSD 2.2), and also in samples having high buffer capacities. However, a predigestion step with pepsin has been suggested for samples containing proteinase inhibitors (Pedersen \& Eggum, 1983).

The $\mathrm{pH}$-stat method was found to be highly reproducible in an interlaboratory investigation by six laboratories (McDonough et al. 1990).

Results obtained in a recent comparative study of in vitro protein digestibility of nineteen food products by the $\mathrm{pH}$-stat method and the dialysis-cell method (Savoie et al. 1989) were compared with in vivo protein digestibility (Eggum et al. 1989) using the rat balance method of Eggum (1973). The in vivo determinations took place in two different laboratories. In general, good agreements were obtained between results from all four measurements (Savoie et al. 1989).

\section{Discussion}

The $\mathrm{pH}$-stat method seems to be superior to the $\mathrm{pH}$-drop method, probably mainly due to a lower influence of varying buffer capacity of the test material. This method has also been proved to be very reproducible between different laboratories. The method seems therefore to be very suitable for predicting digestibility in many protein sources. However, the proteins investigated hitherto have generally been highly digestible and investigations on a number of feedstuffs with lower protein digestibility have not been reported. Therefore, a general correlation between the initial rate of proton release and protein digestibility has not yet been proved, and the method cannot yet be considered to be applicable to all types of food.

\section{COLORIMETRIC METHODS}

\section{Objective}

To predict starch digestibility or availability, mainly in processed foods.

\section{Principle}

Colorimetric measurements of enzymically liberated glucose or maltose from starch after the specific formation of a light-absorbing dye in the visible spectrum.

\section{Methods}

Starch is generally hydrolysed in two steps either with porcine pancreatic amylase (O'Dea et al. 1981) or with the thermostable microbial amylase, Termamyl (Holm et al. $1988)$ in the first step and with microbial amyloglucosidase (EC 3.2.1.3) in the second step. 
However, pre-incubation with pepsin improves the digestibility of some materials, e.g. bread made from sour dough (Siljeström et al. 1988), probably because of a more rigid protein matrix enclosing the starch. White et al. (1988) supplied $\alpha$-amylase (from porcine pancreas) with microbial amyloglucosidase and pullulanase (EC 3.2.1.41) as substitutions for unavailable mammalian sucrase, maltase, and isomaltase.

Liberated glucose or maltose is measured after reaction with $p$-hydroxybenzoic acid hydrazide (O'Dea et al. 1981), dinitrosalicylic acid (Holm et al. 1988), glucose oxidase (EC 1.1.3.4)-peroxidase (EC 1.11.1.7) (Siljeström et al. 1988), anthrone (Öste et al. 1985) or other reagents that form a light-absorbing product which is measured spectrophotometrically.

\section{Results}

The formation of resistant starch during bread baking was studied by Björck et al. (1986). Although the in vitro digestibility values of low-energy dextrose bulking agents (for use in the treatment of obesity) were found to be lower than in vivo values, the results reported by White et al. (1988) were highly correlated ( $r 0.98)$.

Several other investigations have shown a significant correlation between carbohydrate availability in vitro and in vivo, e.g. O'Dea et al. (1981). For further references, see Le François (1989).

\section{Discussion}

Some of the variants of this method seem to be very suitable for investigating the effect of processing on starch availability. However, the use of microbial enzymes may lead to overestimatations when used for prediction of starch availability at the level of the small intestine which has not been hydrolysed anterior to the ileo-caecal valve. Undigested starch, including resistant starch, is generally easily fermented by the microflora in the large intestine (Björck et al. 1986).

\section{'FILTRATION' METHODS}

\section{Objective}

To predict nutrient digestibility of food at the ileal and/or the faecal level.

\section{Principle}

Enzyme incubations in a closed system followed by measurements of dissolved nutrients. This will usually be based on measurements of the unsolubilized material collected after filtration. However, it may also be based on measurements on the filtrate, or alternatively on one of the separated fractions after centrifugation.

The digestibility is then predicted from the relationship between in vitro solubilizability and in vivo digestibility.

These methods can be divided into single-, two- or multi-enzyme systems performed in one, two, or three incubation steps (Eggum \& Boisen, 1991).

\section{Methods}

Single-enzyme systems include incubations with pepsin (Sheffner et al. 1956), papain ( $E C$ 3.4.22.2) (Buchanan, 1969), trypsin (Maga et al. 1973), pronase (Taverner \& Farrell, 1981) and rennin (EC 3.4.23 4) (Bhatty, 1982). Two-enzyme systems include incubation in two steps with pepsin and trypsin (Saunders et al. 1973), and pepsin and pronase (Dierick et al. 1985). Multi-enzyme systems include one- and two-step systems for simulating the 
Table 1. Multi-enzyme systems used for in vitro incubations

\author{
One-step systems: \\ Intestinal fluids \\ Two-step systems: \\ Pepsin (EC 3.4.23.1) - jejunal fluid \\ Pepsin - pancreatin \\ Three-step systems: \\ Pepsin - pancreatin - rumen fluid \\ Pepsin - pancreatin - fibre-degrading enzymes
}

precaecal digestion and three-step systems for simulating the overall digestion. An overview of the different groups of multi-enzyme systems is given in Table 1.

The methods for the five different groups of multi-enzyme systems are briefly described.

Intestinal fluids. A simple one-step incubation with three different inocula from duodenal fluid incubated for $12 \mathrm{~h}$, or ileal fluid or faeces extract incubated for $48 \mathrm{~h}$, was recently described and investigated in detail by Löwgren et al. (1989). The method was used for measuring in vitro digestibility (disappearance) of various nutrients. Other systems had been described previously (Goering \& Van Soest, 1970; Ehle et al. 1982; Holzgraefe et al. 1985).

Pepsin-jejunal fluid. A two-step incubation with pepsin digestion for $4 \mathrm{~h}$ followed by a further 4-h digestion with pig jejunal fluid was developed by Furuya et al. (1979). The method was used for measuring in vitro digestibility of protein and dry matter. Several improvements of this method were suggested by Clunies \& Leeson (1984) for use in routine analysis in quality control of feeds and feed ingredients for poultry.

Pepsin-pancreatin. A two-step incubation with pepsin digestion for $6 \mathrm{~h}$ followed by a pancreatin digestion for $18 \mathrm{~h}$ in a bacteriostatic borate buffer was developed by Büchmann (1979). In vitro protein digestibility was measured after TCA precipitation of solubilized, but not digested proteins.

Another method for measuring protein digestibility after pepsin and pancreatin digestion for $1 \mathrm{~h}$ each was described by Babinszky et al. (1990). In this method starch degradation was improved by addition of amylase to pancreatin while lipids were removed by preextraction with light petroleum (b.p. $40-60^{\circ}$ ). An alternative method with addition of bile salt and extra lipase to the pancreatin solution was also described.

A third method based on pepsin and pancreatin digestion was described by Boisen \& Fernández $(1991 a)$. The enzymic incubation conditions in this method were modified from those described by Asp et al. (1983). The material (1 g) was incubated with pepsin at pH 2 for $6 \mathrm{~h}$ followed by an incubation with pancreatin at $\mathrm{pH} 6.8$ for $18 \mathrm{~h}$. Chloramphenicol was added to prevent bacterial growth. Solubilized but not fully degraded proteins were precipitated with sulphosalicylic acid and undigested materials were collected using the standardized filtration equipment of Tecator for measuring dietary fibre. Fat was removed from the fibre by washing with ethanol and acetone, and in vitro digestibility of dry matter and $\mathrm{N}$ was measured from analysis of the residue. This method has recently been modified slightly by the introduction of continuous magnetic stirring during the enzymic incubations in order to secure effective starch degradation (Boisen \& Fernández, 1991 b).

Pepsin-pancreatin-rumen fluid. To have a complete in vitro evaluation system the potential-energy value of fibre capable of being degraded by microbial enzymes should be included. As the bacterial population in the hind-gut of pigs seems to be rather similar to that in the rumen (Fonty \& Gouet, 1989), the method of Tilley \& Terry (1963) described 


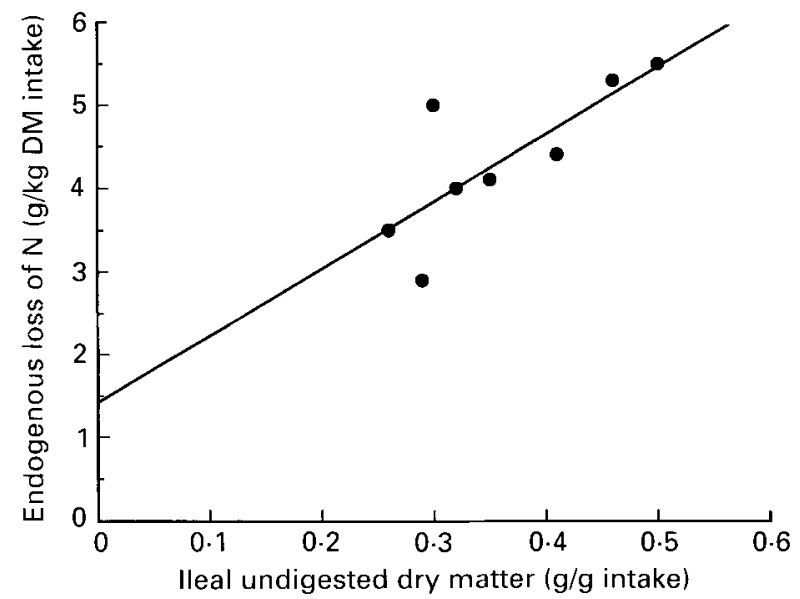

Fig. 1. Relationship between the endogenous loss of nitrogen (calculated from the difference between in vivo and in vitro digested $N$ ) and ileal undigested dry matter (DM) in pigs fed on eight common feedstuffs. From Boisen \& Fernández $(1991 a)$. Regression equation: $y=1 \cdot 41+8 \cdot 1 x$.

for ruminants using rumen fluids as inoculum was applied by Vervaeke et al. (1979) to study hind-gut fermentation of organic matter in pigs. The incubation was performed after pre-incubating the diets with pepsin and pancreatin.

Pepsin-pancreatin-fibre-degrading enzymes. Metz \& Van der Meer (1985) described an in vitro method for predicting faecal digestibility of organic matter after consecutive incubations with pepsin (at $\mathrm{pH}$ ), pancreatin (supplied with lipase, bile salt, and the microbial amylase, Termamyl) and cellulase (EC 3.2.1.4). A slightly modified method was described by Van der Meer \& Perez (1990). In this method pepsin incubation was performed at $\mathrm{pH} 1.5$ and no additions to pancreatin were made.

Boisen \& Fernández (1991 a) developed a method for predicting faecal digestibility of dry matter by supplementing the pepsin-pancreatin method described previously with a third incubation step with the microbial enzyme preparation by Novo, Viscozyme. This preparation is produced from a selected strain of the Aspergillus group and is a multienzyme complex containing a wide range of carbohydrases, including cellulase, hemicellulase, arabinase, xylanase, $\beta$-glucanase and pectinase. In a modified method (Boisen \& Fernández, 1991b) the degradation of fibre, especially in cereals, was improved with another Novo enzyme, Cellulast, produced from a selected strain of Tricoderma reesei, and having a high cellulase activity (Fig. 1).

\section{Results}

The only widely used single-enzyme method is the pepsin method, which is also recognized officially (Association of Official Analytical Chemists, 1984). Recently, Parsons (1991) reported that by using the AOAC (1984) method a good correlation between in vivo and in vitro values was obtained for samples of poultry by-products, but the method was not sensitive enough to test variations in quality of feather meal and of meat meal. However, by reducing the pepsin concentration from 2.0 to $0.02 \mathrm{~g} / 1$ good estimates of protein quality were obtained for these products.

None of the proposed two-enzyme methods has been used widely. However, several multi-enzyme methods have been investigated in detail. Graham et al. (1989) compared the in vitro digestibility (in vitro disappearance), obtained with the method of Löwgren et al. (1989), of dry matter, energy, ash, crude protein $(\mathrm{N} \times 6.25)$, starch, dietary fibre, NSP and 
monosaccharides in five diets with in vivo ileal and faecal apparent digestibility in pigs. These workers obtained good correlations between in vitro values and values for digestibility of starch and crude protein in the small intestine, as well as values for the fermentability of dietary fibre.

The results with the pepsin-jejunal fluid method were found to be closely correlated to faecal digestibility of protein and dry matter in pigs (Furuya et al. 1979) and in poultry (Sakamoto et al. 1980). Dierick et al. (1985) compared results obtained with the pepsin-jejunal method with results from two other two-step in vitro methods, both including pepsin in the first step, but one using pancreatin and the other pronase in the second step. The results from this study indicated that jejunal fluid could replace an appropriate pancreatin solution without reducing accuracy. The in vitro results of protein digestibility obtained with the pepsin-pancreatin method and measured in thirty pig feeds and ingredients were highly correlated with values of apparent faecal digestibility ( $r$ 0-87), but a much lower correlation $(r 0.56)$ was found with apparent ileal digestibility.

The in vitro digestibility of protein obtained from the pepsin-pancreatin method described by Büchmann (1979) was in good agreement with true digestibility values determined on rats for thirty barley samples, but unsatisfactory results were obtained with other cereals (Büchmann, 1979).

Babinszky et al. (1990) investigated seven single feeds and sixteen mixed feeds for pigs by their pepsin-pancreatin method and found an improved correlation to faecal digestible crude protein in fattening pigs by the pre-extraction of lipids with solvent rather than the addition of lipase and bile salt to the incubation mixture with pancreatin.

By the pepsin-pancreatin method developed in our laboratory (Boisen \& Fernández, 1991 a) the in vitro protein digestibilities for a variety of feedstuffs were in general very close to values for true faecal digestibility determined with rats and pigs (Boisen, unpublished results). When using the same technique to predict ileal digestibility of individual amino acids in eight common feedstuffs, we found that the in vitro digestibility of the individual amino acids in general was very close to the in vitro digestibility of $\mathrm{N}$ (Boisen \& Fernández, 1991 a). Furthermore, the results indicated a relationship between (1) undigested dry matter at the ileal level and (2) the difference between in vitro and in vivo undigested $\mathrm{N}$ (or amino acids) at the ileal level (Fig. 1). However, this relationship was not found in a more detailed study with fifty-two feed mixtures varying greatly in composition (Boisen \& Fernández, $1991 \mathrm{~b}$ ). On the other hand, after correction for mean values of the differences between in vitro and in vivo undigested $\mathrm{N}$ (or amino acids) at the ileal level, the apparent ileal digestibility of $\mathrm{N}$ (or amino acids) could still be predicted with considerable accuracy (Boisen \& Fernández, $1991 b$ ).

Vervaeke et al. (1989) demonstrated that after pre-incubation with pepsin and pancreatin, the hind-gut fermentation of organic matter could be estimated with considerable accuracy after incubation with rumen fluid for $48 \mathrm{~h}$. However, several investigations with ruminant feedstuffs have shown that microbial fermentation can be simulated by the use of microbial enzymes (Aufrere \& Michalet-Doreau, 1988). In our laboratory (Boisen, unpublished results) we found a close relationship for a variety of feed mixtures between results of drymatter digestibility obtained after incubation with pepsin, pancreatin, and rumen fluid for $48 \mathrm{~h}$ according to Vervaeke et al. (1989) and results obtained when rumen fluid was replaced with a mixture of Viscozyme and incubated for only $18 \mathrm{~h}$.

Further studies in our laboratory (see Boisen \& Fernández, $1991 \mathrm{~b}$ ) have demonstrated that a general relationship between in vitro digestibility of organic matter and faecal digestibility of energy in a great variety of single feedstuffs and mixtures is obtained after a three-step incubation, with a sequence of pepsin, pancreatin and a mixture of fibredegrading enzymes. 
Table 2. Correlation analyses of the relationship between in vivo (pig) digestibility and results from multi-enzymic in vitro methods simulating precaecal digestion

\begin{tabular}{|c|c|c|c|c|c|c|c|}
\hline$n$ & Feed* & & & Equation $\dagger$ & $r$ & RSD+ & Reference \\
\hline \multicolumn{8}{|c|}{ Faecal level } \\
\hline 7 & $\mathrm{CF}$ & $\mathrm{dN}$ & $=$ & $-60 \cdot 9+1.70 \mathrm{dNm}$ & 0.98 & $1 \cdot 2$ & Furuya et al. (1979) \\
\hline 7 & $\mathrm{CF}$ & $\mathrm{dDM}$ & $=$ & $8 \cdot 1+1 \cdot 04 \mathrm{dDMm}$ & $0 \cdot 98$ & $1 \cdot 1$ & Furuya et al. (1979) \\
\hline 30 & $\mathrm{SF}+\mathrm{CF}$ & $\mathrm{dN}$ & $=$ & $7.3+0.85 \mathrm{dNm}$ & $0 \cdot 87$ & $6 \cdot 7$ & Dierick et al. (1985) \\
\hline 7 & $\mathrm{SF}$ & CPd & $=$ & $-12 \cdot 2+0.97 \mathrm{CPdm}$ & 0.99 & $17 \cdot 4$ & Babinszky et al. (1990) \\
\hline 16 & $\mathrm{CF}$ & CPd & $=$ & $-29 \cdot 1+0 \cdot 11 \mathrm{CPdm}$ & $0 \cdot 95$ & $6 \cdot 2$ & Babinszky et al. (1990) \\
\hline 61 & $\mathrm{SF}$ & $\mathrm{dN}$ & $=$ & $0.7+0.97 \mathrm{dNp}$ & $0 \cdot 93$ & $6 \cdot 3$ & Boisen \& Fernández (1991 $b$ ) \\
\hline 52 & $\mathrm{CF}$ & $\mathrm{dN}$ & $=$ & $-7 \cdot 4+1.09 \mathrm{dNp}$ & 0.85 & $2 \cdot 7$ & Boisen \& Fernández (1991 $b$ ) \\
\hline \multicolumn{8}{|c|}{ Ileal level } \\
\hline 30 & $\mathrm{SF}+\mathrm{CF}$ & $\mathrm{dN}$ & $=$ & $24 \cdot 8+0 \cdot 56 \mathrm{dNm}$ & 0.56 & $6 \cdot 7$ & Dierick et al. (1985) \\
\hline 7 & SF & dDM & $=$ & $-32 \cdot 5+1 \cdot 47 \mathrm{dDMm}$ & 0.97 & $1 \cdot 5$ & Boisen \& Fernández (1991 a) \\
\hline 7 & $\mathrm{SF}$ & $\mathrm{dE}$ & $=$ & $-6 \cdot 5+1 \cdot 11 \mathrm{dDMm}$ & $0 \cdot 97$ & $1 \cdot 5$ & Boisen \& Fernández (1991 $a)$ \\
\hline 52 & $\mathrm{CF}$ & $\mathrm{dE}$ & $=$ & $1.9+0.83 \mathrm{dOMm}$ & 0.76 & $3 \cdot 5$ & Boisen \& Fernández $(1991 b)$ \\
\hline 52 & $\mathrm{CF}$ & $\mathrm{dN}$ & $=$ & $29 \cdot 9+0 \cdot 60 \mathrm{dNp}$ & 0.68 & $3 \cdot 2$ & Boisen \& Fernández (1991 b) \\
\hline 52 & $\mathrm{CF}$ & dLYS & $=$ & $14 \cdot 5+0.83 \mathrm{dLYSp}$ & 0.78 & $2 \cdot 8$ & Boisen \& Fernández (1991 b) \\
\hline 52 & $\mathrm{CF}$ & dMET & $=$ & $15 \cdot 3+0.83 \mathrm{dMETp}$ & 0.74 & $2 \cdot 3$ & Boisen \& Fernández (1991 b) \\
\hline 52 & $\mathrm{CF}$ & dTHR & $=$ & $34 \cdot 6+0 \cdot 54 \mathrm{dTHRp}$ & $0 \cdot 61$ & $3 \cdot 7$ & Boisen \& Fernández (1991 b) \\
\hline
\end{tabular}

* CF, compound feeds; SF, single feedstuffs.

$\dagger \mathrm{dN}$, nitrogen digestibility; dDM, dry-matter digestibility; dOM, organic-matter digestibility; dE, energy digestibility; dLYS, lysine digestibility; dMET, methionine digestibility; dTHR, threonine digestibility; m, measured value in vitro; $\mathrm{p}$, predicted value from in vitro measurements; $\mathrm{CPd}$, crude protein $(\mathrm{N} \times 6.25)$ digested (g/kg dry matter).

+ Residual standard deviation.

Table 3. Correlation analyses of the relationship between in vivo (pig) digestibility and results from multi-enzymic in vitro methods simulating overall digestion

\begin{tabular}{|c|c|c|c|c|c|c|c|}
\hline$n$ & Feed* & & & Equationt & $r$ & RSD & Reference \\
\hline 34 & $\mathrm{SF}+\mathrm{CF}$ & $\mathrm{dOM}$ & $=$ & $-1.8+0.99 \mathrm{dOMm}$ & 0.91 & $3 \cdot 8$ & Metz \& Van der Meer (1985) \\
\hline 16 & $\mathrm{CF}$ & $\mathrm{dOM}$ & $=$ & $-1 \cdot 0+0.98 \mathrm{dOMm}$ & $0 \cdot 85$ & $2 \cdot 7$ & Metz \& Van der Meer (1985) \\
\hline 89 & $\mathrm{CF}$ & $\mathrm{dOM}$ & $=$ & $12 \cdot 5+0 \cdot 80 \mathrm{dOMm}$ & 0.92 & $2 \cdot 0$ & Van der Meer \& Perez (1990) \\
\hline 7 & $\mathrm{SF}$ & $\mathrm{dDM}$ & $=$ & $-4 \cdot 6+1 \cdot 02 \mathrm{dDMm}$ & 0.97 & 1.9 & Boisen \& Fernández $(1991 a)$ \\
\hline 7 & SF & $\mathrm{dE}$ & $=$ & $-8 \cdot 1+1 \cdot 07 \mathrm{dDMm}$ & 0.95 & $2 \cdot 5$ & Boisen \& Fernández $(1991 a)$ \\
\hline 51 & SF & $\mathrm{dE}$ & $=$ & $-19 \cdot 1+1 \cdot 16 \mathrm{dOMm}$ & 0.98 & $3 \cdot 2$ & Boisen \& Fernández (1991 $b$ ) \\
\hline 52 & $\mathrm{CF}$ & $\mathrm{dE}$ & $=$ & $-24.9+1 \cdot 23 \mathrm{dOMm}$ & $0-92$ & $2-2$ & Boisen \& Fernández (1991 b) \\
\hline
\end{tabular}

* CF, compound feeds; SF, single feedstuffs.

$\dagger$ dDM, Dry-matter digestibility; dOM, organic matter digestibility; dE energy digestibility; m, measured value in vitro.

† Residual standard deviation.

Correlation analyses of in vitro and in vivo digestibility from the evaluation of multienzyme in vitro methods are summarized in Tables 2 and 3.

\section{Discussion}

The 'filtration' methods appear to give valuable results for predicting faecal and ileal digestibility in simple-stomach animals. Table 2 shows that the results from in vitro methods which simulate precaecal digestion are very closely correlated with digestibility 
measured at the faecal level in pigs. However, it has been argued that due to extensive fermentation in the large intestine of pigs such in vitro methods should be validated on the basis of ileal digestibility data from pigs, and may also be useful for predicting faecal digestibility in poultry, which have a much lower fermentation in the hind-gut (Clunies \& Leeson, 1984).

Nevertheless, Dierick et al. (1985) found a much lower correlation between their in vitro and in vivo data when comparing ileal instead of faecal digestibility of protein. However, this was explained by the authors to be partly due to the lack of identity for many of the investigated samples, and partly due to the large amount of endogenous protein.

In vitro digestibility of protein and amino acids varies much less between feedstuffs than the in vivo values (Boisen \& Fernández, $1991 a$ ). Much of the variation found in vivo is due to different protein levels in the diets. Thus, the endogenous losses of protein (and amino acids) result in a lower apparent digestibility when the protein level in the ration is reduced. Therefore, only after correction for the endogenous losses is it possible to compare in vitro digestibility with apparent digestibility at the ileal or the faecal level (Boisen \& Fernández, $1991 b)$.

Table 3 shows that the results obtained from in vitro methods which simulate overall digestibility are very closely correlated to faecal digestibility of organic matter and energy. Compared with single feedstuffs, lower correlations between in vivo and in vitro values were generally found for compound feeds due to a lower range of digestibility. On the other hand, the lower variation in the chemical composition also results in lower RSD values for compound feeds.

\section{GENERAL DISCUSSION}

\section{FACTORS INFLUENCING DIGESTIBILITY IN VITRO}

\section{Enzyme specificity}

During digestion in vivo as in vitro, the most potent factors are the enzymes. The specificities of the enzymes determine which bonds are hydrolysed. However, the hydrolysis of a particular bond depends on the access of the enzyme to the substrate. Therefore, the degradation of other bonds by enzymes with other specificities will influence the total degradation. For that reason it is recommended that in vitro incubations include the same enzymes as those occurring in the digestive tract. This should be possible by using intestinal fluids as described by Furuya et al. (1979) and Löwgren et al. (1989). However, such methods give problems with standardization and, furthermore, these enzyme preparations are not commercially available.

On the other hand, it has been found that the substitution of ileal fluid with a pancreatin solution does not reduce the relationship between in vivo and in vitro values (Dierick et al. 1985). In the same study it was also found that incubation with a pancreatin solution gave similar results to those obtained with the mobile nylon-bag technique (Sauer et al. 1983, 1989), which can be considered as an intermediate between in vivo and in vitro methods. In fact, many in vitro methods are based on consecutive incubations with pepsin and pancreatin, suggesting that pancreatin contains all the necessary enzymes for solubilizing the potentially digestible nutrients. However, amylase activity in pancreatin can become limiting for starch degradation (Babinszky et al. 1990), while fat digestion needs the addition of bile acid. To the knowledge of the authors, no relevant studies on in vitro digestibility of fat have been published. Alternatively, the fat may be pre-extracted (Babinszky et al. 1990; Van der Meer \& Perez, 1990) or the most easily extractable fat can be washed out from the filter with acetone (Boisen \& Fernández, 1991 $a, b$ ). 
Table 4. Variation in conditions for pepsin (EC 3.4.23.1) incubations

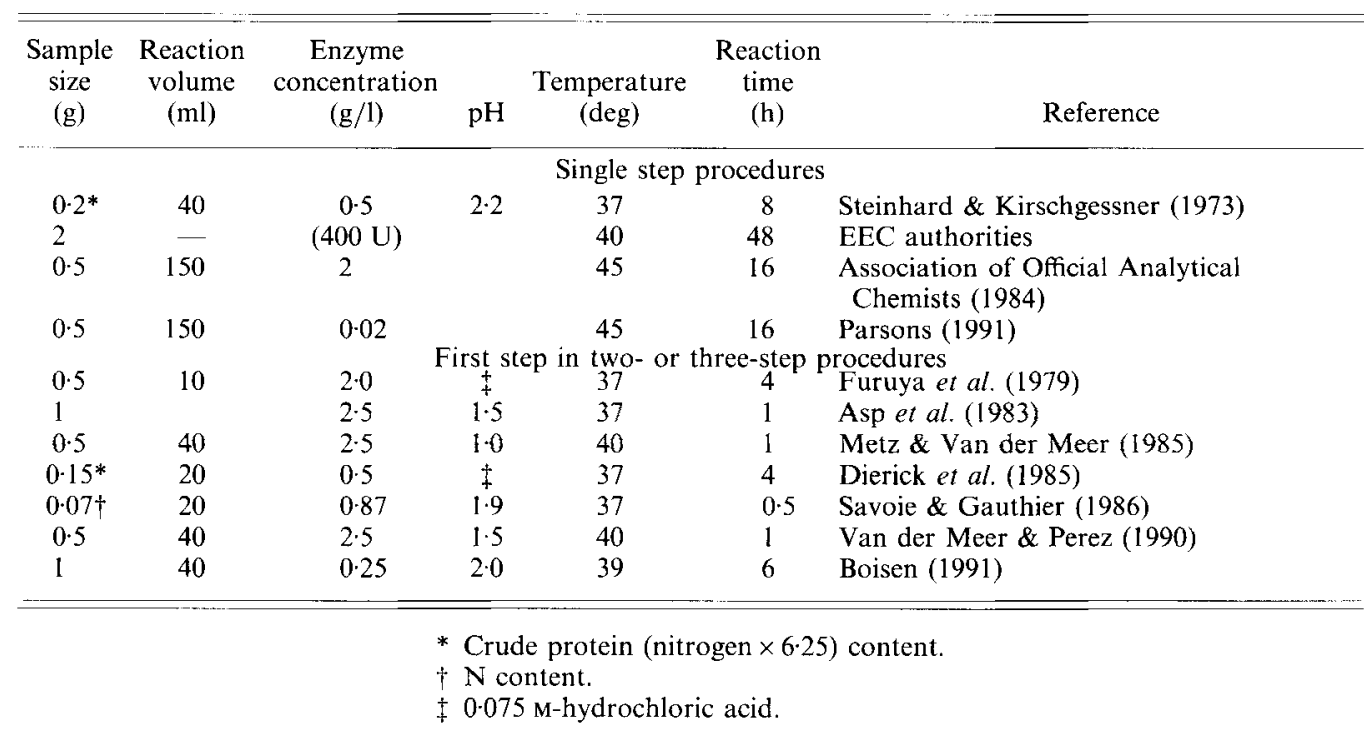

The degradation of dietary fibre, which can only take place by the action of microbial enzymes, can be simulated by rumen fluid (Vervaeke et al. 1989), caecal fluid (Ahrens $e t$ al. 1991), faeces extract (Löwgren et al. 1989), or an appropriate enzyme complex of microbial carbohydrases (Boisen \& Fernández, $1991 a, b$ ).

Despite the complexity of digestion, very simple in vitro methods incorporating only one enzyme seem to give valuable information, especially with investigations of such reactions as the influence of processing on protein digestibility in certain feedstuffs (Parsons, 1991). However, for such purposes even simpler methods may be used, such as solubility measurements in potassium hydroxide (2 g/l) (Araba \& Dale, 1990; Parsons, 1991).

\section{Enzyme activity}

The activity of the enzyme is also very important, particularly in methods where initial digestibility rates are measured. Several factors, such as concentration, temperature, $\mathrm{pH}$, stability, activators, inhibitors and incubation time, will affect enzyme activities.

Some of the variable conditions of pepsin incubations in published methods are compared in Table 4, and a great variation in most conditions can be seen. Thus, the sample size in some methods depends on the weight of the material and in others on the $\mathrm{N}$ content. Other variables are reaction volume, $10-150 \mathrm{ml} ; \mathrm{pH}, 1 \cdot 0-2 \cdot 2 ;$ temperature, $37-45^{\circ}$; reaction time, $0.5-48 \mathrm{~h}$. Finally, the pepsin concentration varies from 0.02 to $2.5 \mathrm{~g} / \mathrm{l}$. However, pepsin concentrations are not directly comparable, as preparations with different activities have been used.

The enzyme activity is also influenced by several factors in the sample itself. In general, fibre and ANF will reduce in vitro enzyme activities. Thus, the activity of pancreatic enzymes is inhibited by most purified components of dietary fibre (Schneeman, 1982; Ikeda \& Kusano, 1983) and also by the indigestible residues from food in general (Morón et al. 1989), while pectin may lead to an elevation of enzyme activity (Schneeman, 1982).

The mechanism of inhibition by most fibres might be due to absorption of enzymes into the fibre matrix (Schneeman, 1978), or unspecific bindings to the fibres (Ikeda \& Kusano, 
1983). Similarly, phytate can reduce digestibility by formation of protein-phytate complexes (Lathia et al. 1987).

The effects of ANF and fibre in vitro are greatly dependent on the experimental conditions. With multi-enzyme assays the reduction in enzyme activity caused by fibre is generally much lower than that found with single-enzyme digestion (Howard \& Mahoney, 1989). The pepsin-pancreatin method applied in our laboratory was also found to be influenced only to a slight degree by various fibre types and ANF (Boisen, unpublished results). Similarly, very little effect of ANF has been observed in situ with the mobile nylonbag technique (Van der Poel, 1990).

\section{Sample and particle size}

At least two important factors are influenced by sample size : representative sampling and relative losses during transferring processes in the procedure. Because of this, the samples should be of constant size and preferably not smaller than $0.5 \mathrm{~g}$.

Normally a smaller particle size is used in in vitro assays than in in vivo tests. This smaller size is necessary in order to ensure representative sampling. It has been shown that an increased particle size requires a longer incubation time in vitro, but final digestibility may not be affected (Löwgren et al. 1989).

\section{Separation technique}

Continuous separation of end-products from undigested material by dialysis or by ultrafiltration techniques generally increases the hydrolysis rate, probably due to removal of end-product inhibition. Cave (1988) found that ultrafiltration techniques with membranes of 500 Dalton pore size were superior to precipitation with TCA acid when in vitro and in vivo estimates of availability of $\mathrm{N}$ and amino acids were compared. On the other hand, in most in vitro methods the great surplus of enzymic capacity ensures that endproduct inhibition has little or no influence on digestibility (Büchmann, 1979).

\section{RELATIONSHIP BETWEEN IN VITRO AND IN VIVO RESULTS}

\section{Prediction of in vivo digestibility}

A close relationship between in vivo and in vitro results has been obtained after in vitro measurements of (1) partly digested materials, e.g. dialysis cell method, (2) initial velocity of digestion, e.g. pH-drop and $\mathrm{pH}$-stat method, (3) complete digestion of susceptible nutrients, e.g. most colorimetric and 'filtration' methods, (4) complete digestion of susceptible protein corrected for endogenous losses of protein (or amino acids), e.g. for prediction of apparent digestibility of protein and amino acids in some 'filtration ' methods.

In some investigations very high correlations have been obtained, particularly when a relatively low number of samples has been included, and when the investigations were performed on (1) single feedstuffs having a relatively high variation in digestibility, (2) compound feeds with a systematic composition, or (3) the same or closely related feedstuffs which have been processed differently.

However, the objective of most of the described in vitro techniques, particularly those from the 'filtration' group, is that they should be able to give a more general prediction of all relevant feedstuffs and mixtures. The results in Tables 2 and 3 strongly indicate that this is possible with multi-enzyme methods, and that these methods are able to predict nutrient digestibility either at the faecal or the ileal level.

The in vivo measurements include variable amounts of endogenous and bacterial matter and are therefore 'apparent' measures of digestibility, while in vitro measurements in most of these methods correspond more to actual or 'true' values of digestibility. In vitro values 

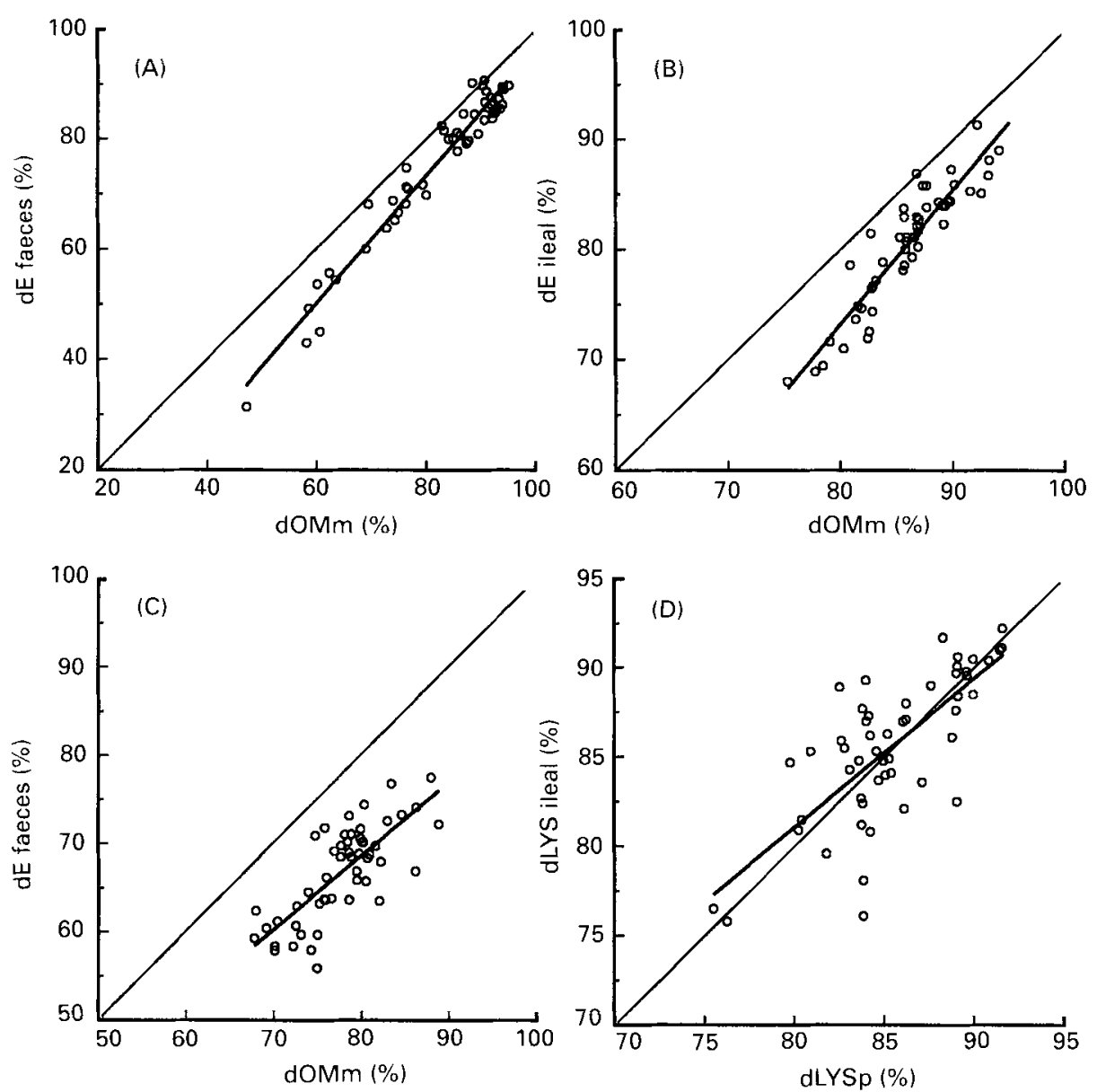

Fig. 2. Relationship between the in vivo digestibility of energy at the faecal level (dE faeces) or the ileal level (dE ileal) and in vitro digestibility of organic matter (dOMm) measured with single feedstuffs (A) or compound feeds ( $\mathrm{B}$ and $\mathrm{C}$ ). (D) Relationship between apparent ileal digestibility of lysine (dLYS ileal) and the predicted digestibility of lysine (dLYSp) based on in vitro measurements of $N$ and the endogenous loss of lysine; for details, see Tables 2 and 3. From Boisen \& Fernández (1991 $b$ ).

from these methods are therefore expected to be higher than in vivo values, as is also seen in Fig. 2, which illustrates some of the results reported by Boisen \& Fernández $(1991 b)$. Many of the differences between in vitro and in vivo digestibility are expected to be due to the bacterial content at the faecal level (Fig. 2(A and B)). However, at the ileal level (Fig. 2(C)) most of these differences are related to endogenous losses, and probably also undigested starch and other potentially digestible nutrients which have been digested (solubilized) in vitro but not digested in vivo. Fig. 2(B and C) shows also that the relationship between in vivo and in vitro digestibility is somehow lower at the ileal level than at the faecal level. This appears to be a general tendency, and is probably due to the lower accuracy of the in vivo measurements and also to higher individual variation between the animals at the ileal level caused by incomplete in vivo digestion of the potentially digestible nutrients.

Fig. 2(D) shows the relationship between apparent ileal digestibility of lysine $(x)$ and the predicted digestibility of lysine when corrected for the endogenous loss of lysine $(y)$. The 


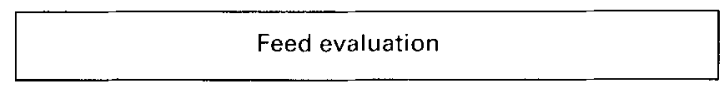

Chemical analyses

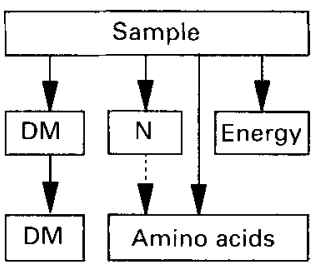

In vitro incubations

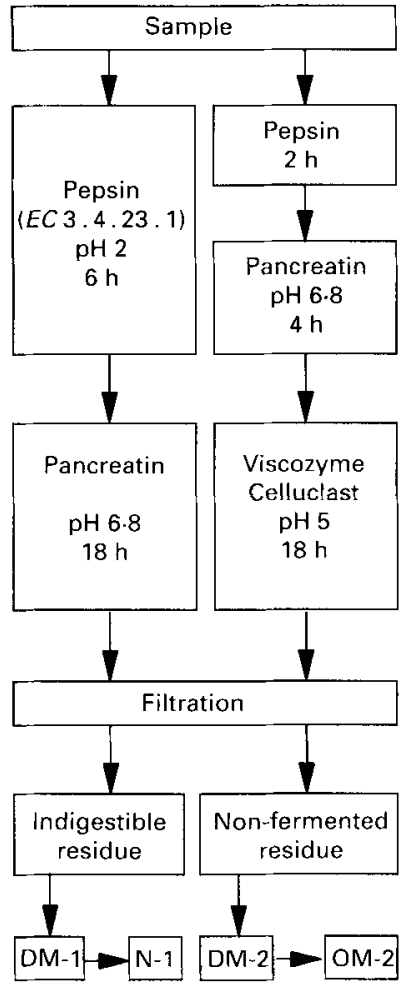

Fig. 3. A complete system for feed evaluation based on chemical analyses supplied with in vitro incubations for predicting precaecal digestibility of amino acids and energy and overall digestibility of energy. Modified from Boisen (1991). DM, dry matter.

correlation obtained is rather low due to a relatively low range of lysine digestibility. However, the RSD value is also low (Table 3).

\section{Prediction of in vivo availability}

The results from most in vitro methods are based on the formation of digestion products that are (1) soluble and eventually not precipitated by precipitating agents or (2) dialysable. The digestion products are those separated from the undigested residue (1) by filtration, ultra-filtration or centrifugation and (2) by dialysing through a membrane with a defined pore size. The in vitro results of amino acid digestibility may be directly correlated with in vivo estimates of availability (Cave, 1988). However, especially in processed foods, the amino acid availability may not always be synonymous with these criteria of digestibility. Therefore, the in vitro results obtained by these methods might be improved by an additional measurement of the availability of amino acids, particularly of lysine which is easily modified by reaction of the $\epsilon$-amino group with sugars or lipids, and furthermore is most often the first limiting amino acid in cereal-based diets.

The availability of lysine may be predicted by the almost classic, but not very specific, Carpenter (1960) method. Alternatively, available lysine can be predicted from a simple 
and specific method with lysine oxidase (EC 1.4.3.14) (Assoumani et al. 1990). In our laboratory we have just started to investigate the use of a specific microbial method (Tuffnell \& Payne, 1985) with mutants of Escherichia coli bacteria which are deficient in the ability to synthesize single essential amino acids, e.g. lysine, methionine or tryptophan.

\section{Prediction of feed value}

Detailed investigations have been performed by several research groups in order to improve the in vitro technique in such a way that all relevant feedstuffs and their mixtures can be included in a general and close relationship between in vitro and in vivo results. This is also necessary if the in vitro technique is to be generally used (1) for analysing the feed ingredients before production of compound feeds with an optimal composition and (2) for controlling the energy and protein value of compound feed with unknown composition.

The final system suggested for feed evaluation based on in vitro measurements includes chemical analyses of dry matter, ash, N, energy and amino acids, combined with two parallel multi-enzyme systems for predicting precaecal digestibility of amino acids and energy and overall digestibility of energy (Fig. 3). From this system the protein value of the food can be calculated from the amino acid composition in the digested protein in relation to ideal protein, while the energy value can be calculated from digested energy, fermented energy and energy loss from the calculated non-utilizable amino acids (Boisen, 1991). The system can be further improved by supplementing with specific analyses of (1) amino acid availability, mainly in processed foods, and (2) ANF and fractions of dietary fibre.

Compared with other chemical methods enzymic degradability provides the most precise estimate of the digestibility of pig feedstuffs (Van der Meer \& Perez, 1990). A similar conclusion for ruminant feedstuffs has previously been made by Aufrere \& MichaletDoreau (1988). Furthermore, the prediction of feed value may be improved by supplementing analyses of chemical fractions, like crude fibre, in a multiple regression (Van der Meer \& Perez, 1990).

An alternative method using near-infrared reflectance spectrophotometry (NIRS) has the potential to be developed into a reliable method for predicting digestibility (Harrison et al. 1991; Van Leeuwen et al. 1991). This method is much more rapid than in vitro methods, but is also dependent on calibration with a relatively large number of samples with known in vivo values, which is the major barrier to further development (Harrison et al. 1991). However, for this purpose reliable in vitro results can be of great importance.

\section{CONCLUSIONS}

Several enzymic in vitro methods for investigating digestibility of nutrients in foods have been developed.

The objectives of the methods are (1) to study kinetics of digestion as influenced by various factors, (2) to predict digestibility of one or more nutrients in processed and closely related foods, or (3) to predict digestibility of nutrients in all relevant foods for simplestomach animals, e.g. pigs, poultry or man.

The principles of the methods depend to some degree on the objectives. The digestibility values may be based on measurements of (1) initial velocity of digestion with or without removal of digestion products which may inhibit the digestion, (2) partial digestion in single- or multi-enzyme systems, and (3) complete digestion of susceptible nutrients in multi-enzyme systems.

The choice of enzymes and incubation conditions and the need for equipment are also dependent on the objectives. Single-enzyme methods can be useful for predicting the digestibility of single nutrients, e.g. protein by the use of pepsin, or starch by the use of 
amylase. However, as the digestion of one nutrient generally is influenced by the digestion of the other nutrients, multi-enzyme methods are believed to give the most reliable values.

For simulating precaecal digestion, satisfactory enzyme mixtures may be prepared from pure enzyme preparations, pancreatin, or intestinal fluids. For simulating post-ileal fermentation, incubations may use live bacteria from intestinal or rumen fluids or from extracts of faeces. Compared with intestinal fluids, pancreatin is (1) easy to obtain (commercially available), (2) more constant and well defined in composition, which increases reproducibility within the laboratory and in particular between laboratories, (3) free from microbial enzymes, which makes it possible to measure digestion with purified endogenous enzymes and microbial enzymes separately and therefore also more correctly to predict the energy value. This suggestion is based on the lower energy value of fermented materials compared with carbohydrates digested in the small intestine. Prediction of fibre degradability by the use of commercially available fibre-degrading enzymes, rather than living bacteria, improves standardization and reproducibility and reduces incubation time.

Fibre and ANF, like trypsin inhibitors, tannins, lectins, glucosinolates and alkaloids, which depress nutrient digestibility in vivo, have a much smaller effect on measurements in vitro (as well as in situ by the mobile nylon-bag technique). This is due to the specific and quantitative action of these substances on in vivo conditions.

For kinetic studies, the dialysis-cell method seems to be superior to other methods. The $\mathrm{pH}-\mathrm{drop}$ and $\mathrm{pH}$-stat methods can be useful for studying variations in protein digestibility within related foods, e.g. processed foods. However, the pH-stat method seems to be superior to the $\mathrm{pH}$-drop method, especially for foods with a high buffer capacity.

For general and routine use in practical feed evaluation, multi-enzyme incubations in two or three steps followed by a collection of undigested materials by filtration have been developed. These methods have been demonstrated to be able to predict precaecal and overall digestibility respectively in a great variety of foods. Specific analyses of available amino acids, ANF and fractions of dietary fibre may improve the prediction of energy and protein value of the foods.

In future, reliable in vitro methods may also become the basis for the development of other methods like NIRS, which is an even simpler and more rapid but at present a less precise method of predicting digestibility than enzymic in vitro methods.

\section{REFERENCES}

Ahrens, F., Schön, J. \& Schmitz, M. (1991). A discontinuous in vitro technique for measuring hind-gut fermentation in pigs. In Digestive Physiology in Pigs, pp. 226-230 [M. W. A. Verstegen, J. Huisman and L. A. den Hartzog, editors]. Wageningen: Puduc.

Araba, M. \& Dale, N. M. (1990). Evaluation of protein solubility as an indicator of overprocessing soybean meal. Poultry Science 69, 76-83.

Asp, N.-G., Johansson, C.-G., Hallmer, H. \& Siljeström, M. (1983). Rapid enzymatic assay of insoluble and soluble dietary fiber. Journal of Agricultural and Food Chemistry 31, 476-482.

Association of Official Analytical Chemists (1984). Official Methods of Analysis, 14th ed. Washington, DC: AOAC.

Assoumani, M. B., Nguyen, N. P., Lardinois, P. F., van Bree, I., Baudichau, A. \& Bruyer, D. C. ([990). Use of a lysine oxidase electrode for lysine determination in Maillard model reactions and in soybean meal hydrolysates. Zeitschrift für Lebensmitlelwissenschaft und-Technologie 23, 322-327.

Aufrere, J. \& Michalet-Doreau, B. (1988). Comparison of methods for predicting digestibility of feeds. Animal Feed Science and Technology 20, 203-218.

Babinszky, L., van der Meer, J. M., Boer, H. \& den Hartog, L. A. (1990). An in-vitro method for prediction of the digestible crude protein content in pig feeds. Journal of the Science of Food and Agriculture 50, 173-178.

Bhatty, R. S. (1982). In vitro hydrolysis of skim milk and pea proteins by pepsin and rennin. Canadian Institute of Food Science and Technology Journal 15, 101-108.

Björck, I., Nyman, M., Pedersen, B., Siljeström, M., Asp, N.-G. \& Eggum, B. O. (1986). On the digestibility of starch in wheat bread. Studies in vitro and in vivo. Journal of Cereal Science 4, 1-11. 
Boisen, S. (1991). A model for feed evaluation based on in vitro digestible dry matter and protein. In Digestion in vitro [M. F. Fuller, editor]. Slough: Commonwealth Agricultural Bureaux International. (In the Press.)

Boisen, S., Agergaard, N., Rotenberg, S. \& Kragelund, Z. (1985). Effects of gut flora on intestinal activities of trypsin, chymotrypsin, elastase and amylase in growing rats fed diets with cellulose, pectin or sand. Zeitschrift für Tierphysiologie, Tierernährung und Futtermittelk unde 53, 245-254.

Boisen, S. \& Fernández, J. A. (1991 a). In vitro digestibility of energy and amino acids in pig feeds. In Digestive Physiology in Pigs, pp. 231-236 [M. W. A. Verstegen, J. Huisman and L. A. den Hartzog, editors]. Wageningen: Puduc.

Boisen, S. \& Fernández, J. A. (1991 b). In vitro digestion as a basis for the prediction of energy and protein value in pig feeds. 42nd Annual Meeting of European Association of Animal Production, Berlin, Report (8 pp) presented at meeting September 1991.

Brulé, D. \& Savoie, L. (1988). In vitro digestibility of protein and amino acids in protein mixtures. Journal of the Science of Food and Agriculture 43, 361-372.

Buchanan, R. A. (1969). In vivo and in vitro methods of measuring nutritive value of leaf-protein preparations. British Journal of Nutrition 23, 533-545.

Büchmann, N. B. (1979). In vitro digestibility of protein from barley and other cereals. Journal of the Science of Food and Agriculture 30, 583-589.

Carpenter, K. J. (1960). The estimation of the available lysine in animal-protein foods. Biochemical Journal 77, 604-610.

Cave, N. A. (1988). Bioavailability of amino acids in plant feedstuffs determined by in vitro digestion, chick growth assay, and true amino acid availability methods. Poultry Science 67, 78-87.

Clunies, M. \& Leeson, S. (1984). In vitro estimation of dry matter and crude protein digestibility. Poultry Science 63, 89-96.

Corring, T. (1980). The adaptation of digestive enzymes to the diet: its physiological significance. Reproduction, Nutrition, Développement 20, 1217-1235.

Corring, T., Juste, C. \& Lhoste, E. F. (1989). Nutritional regulation of pancreatic and biliary secretions. Nutrition Research Reviews 2, 161-180.

Dierick, N., Vervaeke, I., Decuypere, J. \& Hendrickx, H. (1985). Protein digestion in pigs measured in vivo and in vitro. In Digestive Physiology in the Pig, pp. 329-332 [A. Just, H. Jørgensen and J. A. Fernández, editors]. Copenhagen: National Institute of Animal Science.

Drake, A. (1991). Simultaneous in vitro prediction of precaecal protein and carbohydrate digestion by pigs. In Digestion in vitro [M. F. Fuller, editor]. Slough: Commonwealth Agricultural Bureaux International. (In the Press.)

Eggum, B. O. (1973). A study of certain factors influencing protein utilization in rats and pigs. Report of National Institute of Animal Science, Copenhagen, no. 406. Copenhagen: National Institute of Animal Science.

Eggum, B. O. (1991). The influence of dietary fibre on protein digestion and utilization. In Dietary Fibre - A Component of Food - Nutritional Function in Health and Disease. (In the Press.)

Eggum, B. O., Andersen, J. O. \& Rotenberg, S. (1982). The effect of dietary fibre level and microbial activity in the digestive tract on fat metabolism in rats and pigs. Acta Agricultura Scandinavica 32, 145-150.

Eggum, B. O. \& Boisen, S. (1991). In vitro techniques of measuring digestion. In Digestive Physiology in Pigs, pp. 213-225 [M. W. A. Verstegen, J. Huisman and L. A. den Hartzog, editors]. Wageningen: Puduc.

Eggum, B. O., Hansen, I. \& Larsen, T. (1989). Protein quality and digestible energy of selected foods determined in balance trials with rats. Plant Foods for Human Nutrition 39, 13-21.

Ehle, F. R., Jeraci, J. L., Robertson, J. B. \& Van Soest, P. J. (1982). The influence of dietary fiber on digestibility, rate of passage and gastrointestinal fermentation in pigs. Journal of Animal Science 55, 1071-1081.

Elbers, A. R. W., Den Hartog, L. A., Verstegen, M. W. A. \& Zandstra, T. (1989). Between- and within-herd variation in the digestibility of feed for growing-finishing pigs. Livestock Production Science 23, $183-193$.

Fonty, G. \& Gouet, P. (1989). Fibre-degrading microorganisms in the monogastric digestive tract. Animal Feed Science and Technology 23, 91-107.

Friedman, H. I. \& Nylund, B. (1980). Intestinal fat digestion, absorption, and transport. A review. American Journal of Clinical Nutrition 33, 1108-1139.

Furuya, S., Sakamoto, K. \& Takahashi, S. (1979). A new in vitro method for the estimation of digestibility using the intestinal fluid of the pig. British Journal of Nutrition 41, 511-520.

Galibois, I., Savoie, L., Simoes Nunes, C. \& Rérat, A. (1989). Relation between in vitro and in vivo assessment of amino acid availability. Reproduction, Nutrition, Développement 29, 495-507.

Gauthier, S. F., Vachon, C., Jones, J. D. \& Savoie, L. (1982). Assessment of protein digestibility by in vitro enzymatic hydrolysis with simultaneous dialysis. Journal of Nutrition 112, 1718-1725.

Gauthier, S. F., Vachon, C. \& Savoie, L. (1986). Enzymatic conditions of an in vitro method to study protein digestion. Journal of Food Science 51, 960-964.

Goering, H. K. \& Van Soest, P. J. (1970). Forage Fiber Analyses (Apparatus, Reagents, Procedures and Some Applications). Agriculture Handbook, no. 379. Washington, DC: Agricultural Research Service, US Department of Agriculture.

Graham, H., Löwgren, W. \& Åman, P. (1989). An in vitro method for studying digestion in the pig. 2. Comparison with in vivo ileal and faecal digestibilities. British Journal of Nutrition 61, 689-698. 
Grimble, G. K. \& Silk, D. B. A. (1989). Peptides in human nutrition. Nutrition Research Reviews 2, 87-108.

Gurr, M. I., Borlak, N. \& Ganatra, S. (1989). Dietary fat and plasma lipids. Nutrition Research Reviews 2, 63-86.

Harrison, M. D., Ballard, M. R. M., Barclay, R. A., Jackson, M. E. \& Stilborn, H. L. (1991). A comparison of true digestibility for poultry and apparent ileal digestibility for swine. A classical in vitro method and NIR spectrophotometry for determining amino acid digestibility. In Digestive Physiology in Pigs, pp. $254-259$ [M. W. A. Verstegen, J. Huisman and L. A. den Hartzog, editors]. Wageningen: Puduc.

Holm, J., Lundquist, I., Björck, I., Eliasson, A.-C. \& Asp, N.-G. (1988). Degree of starch gelatinization, digestion rate of starch in vitro, and metabolic response in rats. American Journal of Clinical Nutrition 47, 1010-1016.

Holzgraefe, D. P., Fahey, G. C. \& Jensen, A. H. (1985). Influence of dietary alfalfa:orchardgrass hay and lasalocid on in vitro estimates of dry matter digestibility and volatile fatty acid concentrations of cecal contents and rate of digesta passage in sows. Journal of Animal Science 60, 1235-1246.

Howard, P. \& Mahoney, R. R. (1989). Effect of dietary fibres on the enzymatic digestion of casein. Food Chemistry 34, 141-146.

Hsu, H. W., Vavak, D. L., Satterlee, L. D. \& Miller, G. A. (1977). A multienzyme technique for estimating protein digestibility. Journal of Food Science 42, 1269-1273.

Ikeda, K. \& Kusano, T. (1983). In vitro inhibition of digestive enzymes by indigestible polysaccharides. Cereal Chemistry 60, 260-263.

Just, A., Jørgensen, H. \& Fernández, J. A. (1985). Correlations of protein deposited in growing female pigs to ileal and faecal digestible crude protein and amino acids. Livestock Production Science 12, 145-159.

Lathia, D., Hoch, G. \& Kievernagel, Y. (1987). Influence of phytate on in vitro digestibility of casein under physiological conditions. Plant Foods for Human Nutrition 37, 229-235.

Le François, P. (1989). In-vitro availability of starch in cereal products. Journal of the Science of Food and Agriculture 49, $499-501$.

Liener, I. E. \& Kakade, M. L. (1980). Protease inhibitors. In Toxic Constituents of Plant Foodstuffs, 2nd ed., pp. 7-71 [I. E. Liener, editor]. New York: Academic Press.

Low, A. G. (1980). Nutrient absorption in pigs. Journal of the Science of Food and Agriculture 31, $1087-1130$.

Low, A. G. (1990). Protein evaluation in pigs and poultry. In Feedstuff Evaluation, pp. 91-114 [J. Wiseman and D. J. A. Cole, editors]. London: Butterworths.

Löwgren, W., Graham, H. \& Åman, P. (1989). An in vitro method for studying digestion in the pig. 1. Simulating digestion in the different compartments of the intestine. British Journal of Nutrition 61, 673-687.

McDonough, F. E., Sarwar, G., Steinke, F. H., Slump, P., Garcia, S. \& Boisen, S. (1990). In vitro assay for protein digestibility: interlaboratory study. Journal of the Association of Official Analytical Chemists 73, $622-625$.

Maga, J. A., Lorenz, K. \& Onayemi, O. (1973). Digestive acceptability of proteins as measured by the initial rate of in vitro proteolysis. Journal of Food Science 38, 173-174.

Mason, V. C. (1984). Metabolism of nitrogenous compounds in the large gut. Proceedings of the Nutrition Society 43, 45-53.

Mauron, J., Mottu, F., Bujard, E. \& Egli, R. H. (1955). The availability of lysine, methionine and tryptophan in condensed milk and milk powder. In vitro digestion studies. Archives of Biochemistry and Biophysics $\mathbf{5 9}$, $433-451$.

Mehansho, H., Butler, L. G. \& Carlson, D. M. (1987). Dietary tannins and salivary proline-rich proteins: interactions, induction, and defense mechanisms. Annual Review of Nutrition 7, 423-440.

Metz, S. H. M. \& Van der Meer, J. M. (1985). Nylon bag and in vitro techniques to predict in vivo digestibility of organic matter in feedstuffs for pigs. In Digestive Physiology in the Pig, pp. 373-376 [A. Just, H. Jørgensen and J. A. Fernández, editors]. Copenhagen: National Institute of Animal Science.

Morón, D., Melito, C. \& Tovar, J. (1989). Effect of indigestible residue from foodstuffs on trypsin and pancreatic $\alpha$-amylase activity in vitro. Journal of the Science of Food and Agriculture 47, 171-179.

Moughan, P. J., Schrama, J., Skilton, G. A. \& Smith, W. C. (1989). In-vitro determination of nitrogen digestibility and lysine availability in meat and bone meals and comparison with in-vivo ileal digestibility estimates. Journal of the Science of Food and Agriculture 47, 281-292.

O'Dea, K., Snow, P. \& Nestel, P. (1981). Rate of starch hydrolysis in vitro as a predictor of metabolic responses to complex carbohydrate in vivo. American Journal of Clinical Nutrition 34, 1991-1993.

Öste, R., Sjödin, P., Jägerstad, M., Björck, I. \& Dahlqvist, A. (1985). Effect of Maillard reaction products on carbohydrate utilization - studies in vitro and in vivo. Food Chemistry 16, 37-47.

Parsons, C. M. (1991). Use of pepsin digestibility, multienzyme $\mathrm{pH}$ change and protein solubility assays to predict in vivo protein quality of feedstuffs. In Digestion in vitro [M. F. Fuller, editor]. Slough: Commonwealth Agricultural Bureaux International. (In the Press.)

Pedersen, B. \& Eggum, B. O. (1981). Prediction of protein digestibility by in vitro procedures based on two multienzyme systems. Zeitschrift für Tierphysiologie, Tierernährung und Futtermittelkunde 45, $190-200$.

Pedersen, B. \& Eggum, B. O. (1983). Prediction of protein digestibility by an in vitro enzymatic pH-stat procedure. Zeitschrift für Tierphysiologie, Tierernährung und Futtermittelkunde 49, 265-277.

Pusztai, A. (1989). Biological effects of dietary lectins. In Recent Advances of Research in Antinutritional Factors in Legume Seeds, pp. 17-29 [J. Huisman, T. F. B. van der Poel and I. E. Liener, editors]. Wageningen: Puduc.

Robbins, R. C. (1978). Effect of ratio of enzymes to substrate on amino acid patterns released from proteins in vitro. International Journal for Vitamin and Nutrition Research 48, 44-53. 
Roehrig, K. L. (1984). Carbohydrate Biochemistry and Nutrition. Westport, CT.: AVI Publishing Co. Inc.

Sakamoto, K., Asano, T., Furuya, S. \& Takahashi, S. (1980). Estimation of in vivo digestibility with the laying hen by an in vitro method using the intestinal fluid of the pig. British Journal of Nutrition 43, 389--391.

Sarwar, G., Savoie, L., Peace, R. W. \& Parent, G. (1989). A comparison of in vitro enzymatic and rat balance methods for measuring digestibility of protein and amino acids in foods. In Absorption and Utilization of Amino Acids, vol. 3, pp. 231-242 [M. Friedman, editor]. Baton Rouge, LA: CRC Press.

Satterlee, L. D., Kendrick, J. G., Jewell, D. K. \& Brown, W. D. (1981). Estimating apparent protein digestibility from in vitro assays. In Protein Quality for Humans: Assessment and in vitro Estimation, pp. 316-339 [C. E. Bodwell, J. S. Adkins and D. T. Hopkins, editors]. Westport, CT.: AVI Publishing Co. Inc.

Sauer, W. C., den Hartog, L. A., Huisman, J., van Leeuwen, P. \& de Lange, C. F. M. (1989). The evaluation of the mobile nylon bag technique for determining the apparent protein digestibility in a wide variety of feedstuffs for pigs. Journal of Animal Science 67, 432-440.

Sauer, W. C., Jørgensen, H. \& Berzins, R. (1983). A modified nylon bag technique for determining apparent digestibilities of protein in feedstuffs for pigs. Canadian Journal of Animal Science 63, 233-237.

Sauer, W. C. \& Ozimek, L. (1986). Digestibility of amino acids in swine: results and their practical applications. A review. Livestock Production Science 15, 367-388.

Saunders, R. M., Connor, M. A., Booth, A. N., Bickoff, E. M. \& Kohler, G. O. (1973). Measurement of digestibility of alfalfa protein concentrates by in vivo and in vitro methods. Journal of Nutrition 103, 530-535.

Savoie, L. \& Charbonneau, R. (1990). Specific role of endopeptidases in modulating the nature of protein digestion products. Plant Foods for Human Nutrition 40, 233-242.

Savoie, L., Charbonneau, R. \& Parent, G. (1989). In vitro amino acid digestibility of food proteins as measured by the digestion cell technique. Plant Foods for Human Nutrition 39, 93-107.

Savoie, L. \& Gauthier, S. F. (1986). Dialysis cell for the in vitro measurement of protein digestibility. Journal of Food Science 51, 494498.

Schneeman, B. O. (1978). Effect of plant fiber on lipase, trypsin and chymotrypsin activity. Journal of Food Science 43, 634635 .

Schneeman, B. O. (1982). Pancreatic and digestive function. In Dietary Fiber in Health and Disease, pp. 73-83 [G. V. Vahouny and D. Kritchevsky, editors]. New York: Plenum Publishing Corporation.

Sheffner, A. L., Eckfeldt, G. A. \& Spector, H. (1956). The pepsin-digest-residue (PDR) amino acid index of net protein utilization. Journal of Nutrition 60, 105-120.

Siljeström, M., Björk, I., Eliasson, A.-C., Lönner, C., Nyman, M.\& Asp, N.-G. (1988). Effects of polysaccharides during baking and storage of bread. In vitro and in vivo studies. Cereal Chemistry 65, 1-8.

Steinhart, H. \& Kirchgessner, M. (1973). [In vitro digestion apparatus for the enzymic hydrolysis of proteins.] Archiv für Tierernährung 23, $449-459$.

Tanksiey, T. D. \& Knabe, D. A. (1984). lieal digestibilities of amino acids in pig feeds and their use in formulating diets. In Recent Advances in Animal Nutrition 1984, pp. 75-95 [W. Haresign and D. J. A. Cole, editors]. London: Butterworths.

Taverner, M. R. \& Farrell, D. J. (1981). Availability to pigs of amino acids in cereal grains. 3. A comparison of ileal availability values with faecal, chemical and enzymic estimates. British Journal of Nutrition 46, $173 \cdots 180$.

Tilley, J. M. A. \& Terry, R. A. (1963). A two-stage technique for the in vitro digestion of forage crops. Journal of the British Grassland Society 18, 104-111.

Tuffnell, J. M. \& Payne, J. W. (1985). A colorimetric enzyme assay using Escherichia coli to determine nutritionally available lysine in biological materials. Journal of Applied Bacteriology 58, 333-341.

Vachon, C., Gauthier, S., Jones, J. D. \& Savoie, L. (1983). In vitro enzymatic release of amino acids from alkalitreated proteins containing lysinoalanine. Nutrition Reports International 27, 1303-1313.

Van Leeuwen, P., Verstegen, M. W. A., van Lonkhuijsen, H. J. \& van Kempen, G. J. M. (1991). Near infrared reflectance (NIR) spectroscopy to estimate the apparent ileal digestibility of protein in feedstuffs. In Digestive Physiology in Pigs, pp. 260-265 [M. W. A. Verstegen, J. Huisman and L. A. den Hartzog, editors]. Wageningen: Pudoc.

Van der Meer, J. M. \& Perez, J. M. (1990). In vitro evaluation of European diets for pigs. Prediction of the organic matter digestibility by an enzymatic method or by chemical evaluation. 41st Annual Meeting of European Association of Animal Production, Toulouse, Report (16 pp) presented at meeting July 1990.

Van der Poel, A. F. B. (1990). Effect of processing on bean (Phaseolus vulgaris L.). Protein quality. Thesis, Agricultural University of Wageningen.

Vervaeke, I. J., Decuypere, J. A., Dierick, N. A. \& Henderickx, H. K. (1979). Quantitative in vitro evaluation of the energy metabolism influenced by virginiamycin and spiramycin used as growth promotors in pig nutrition. Journal of Animal Science 49, 846-856.

Vervaeke, I. J., Dierick, N. A., Demeyer, D. I. \& Decuypere, J. A. (1989). Approach to the energetic importance of fibre digestion in pigs. II. An experimental approach to hindgut digestion. Animal Feed Science and Technology 23, 169-194.

White, J.S., Parsons, C. M. \& Baker, D. H. (1988). An in vitro digestibility assay for prediction of the metabolizable energy of low-calorie dextrose polymeric bulking agents. Journal of Food Science 53, 1204-1207.

Wolzak, A., Bressani, R. \& Gómez Brenes, R. (1981). A comparison of in vivo and in vitro estimates of protein digestibility of native and thermally processed vegetable proteins. Plant Foods for Human Nutrition 31, $31-43$.

Printed in Great Britain 